\title{
DAYA TERIMA SERTA ANALISIS KADAR PROTEIN DAN FOSFOR PADA NUGGET CUMI-CUMI DENGAN PENAMBAHAN BAYAM
}

\author{
Nuratira Rasyid ${ }^{1}$, Rudi Hartono ${ }^{2}$, Sunarto ${ }^{2}$ \\ ${ }^{1}$ Alumni Prodi Sarjana Terapan Gizi dan Dietetika Poltekkes Kemenkes Makassar \\ 2Jurusan Gizi, Poltekkes Kemenkes Makassar \\ *) Nuratirarasyid25@gmail.com
}

\begin{abstract}
Along with the times, humans are required to be more practical and efficient in carrying out their lives. This change will certainly have an impact on the human diet, one of which is by consuming fast food. Fast food usually has a weakness in its fiber content, so it is necessary to add vegetables to increase fiber content. The vegetables that will be added in making squid nuggets are spinach, which as we all know spinach contains high nutrients and spinach is also easy to obtain so it can be an alternative source of nutrients. This study aims to determine the acceptability and analysis of protein and phosphorus levels in squid nuggets with the addition of spinach. This research is a laboratory research. Panelists taken were 25 female students and students of D3 Nutrition Study Program and Applied Bachelor of Nutrition and Dietetics Department of Nutrition to determine the acceptance of the best product. The data on the acceptance of squid nuggets with the addition of spinach are grouped, then processed using a computer program, namely Microsoft Exel and SPSS, while the protein content data is obtained from the results of the Kjeldahl method protein test and phosphorus content data is obtained from the phosphorus test results of the AOAC method. The results showed that the most preferred squid nuggets with the addition of spinach were at a concentration of $5 \%$ (X2) with an average protein content of $15.49 \%$ and an average phosphorus content of $0.094 \%$. As for the concentration of $0 \%(X 1)$ with the results of the analysis of the average protein content of $13.45 \%$ and an average phosphorus content of $0.073 \%$. It is recommended that further research be carried out on the analysis of nutrients to determine other nutrients contained in squid nuggets with the addition of spinach.
\end{abstract}

Key words $\quad$ : Squid nuggets, spinach, protein and phosphorus

\section{ABSTRAK}

Seiring dengan perkembangan zaman, manusia dituntut untuk menjadi lebih praktis dan efisien dalam menjalankan kehidupannya. Perubahan ini tentunya akan berakibat pada pola makan manusia, salah satunya adalah dengan mengkonsumsi makanan yang siap saji. Makanan cepat saji biasanya mempunyai kelemahan pada kandungan seratnya, untuk itu diperlukan penambahan sayuran untuk meningkatkan kandungan serat. Adapun sayuran yang akan ditambahkan dalam pembuatan nugget cumi-cumi adalah bayam, dimana seperti kita ketahui bayam mengandung zat gizi yang tinggi dan bayam juga mudah didapatkan sehingga bisa menjadi alternatif sumber zat gizi. Penelitian ini bertujuan untuk mengetahui daya terima serta analisis kadar protein dan fosfor pada nugget cumi-cumi dengan penambahan bayam. Penelitian ini merupakan penelitian laboratorium. Panelis yang diambil adalah 25 orang mahasiswi dan mahasiswa Prodi D3 Gizi dan Sarjana Terapan Gizi dan Dietetika Jurusan Gizi untuk mengetahui daya terima produk terbaik. Data hasil uji daya terima nugget cumi-cumi dengan penambahan bayam dikelompokkan, kemudian diolah dengan menggunakan program computer yaitu Microsoft Exel dan SPSS sedangkan data kandungan protein diperoleh dari hasil uji protein metode Kjeldahl dan data kandungan fosfor diperoleh dari hasil uji fosfor metode AOAC. Hasil penelitian menunjukkan bahwa nugget cumi-cumi dengan penambahan bayam yang paling banyak disukai yaitu pada konsentrasi $5 \%$ (X2) dengan hasil analisis kandungan protein rata-rata 15,49\% dan kandungan fosfor ratarata $0,094 \%$. Sedangkan untuk konsentrasi $0 \%(X 1)$ dengan hasil analisis kandungan protein rata-rata $13,45 \%$ dan kandungan fosfor rata-rata $0,073 \%$. Disarankan agar dilakukan penelitian lebih lanjut mengenai analisis zat gizi untuk mengetahui zat gizi lain yang terkandung pada nugget cumi-cumi dengan penambahan bayam.

Kata kunci $\quad$ : Nugget cumi-cumi, bayam, protein dan fosfor

\section{PENDAHULUAN}

Seiring dengan perkembangan zaman, manusia dituntut untuk menjadi lebih praktis dan efisien dalam menjalankan kehidupannya. Perubahan ini tentunya akan berakibat pada pola makan manusia, salah satunya adalah dengan mengkonsumsi makanan yang siap saji. Bahan makanan ini misalnya terdiri dari daging, ikan dan ayam yang biasa dibuat dalam bentuk nugget (Dewi dkk, 2015).

Nugget merupakan salah satu produk pangan cepat saji yang saat ini dikenal baik oleh masyarakat. Nugget, seperti juga sosis, burger, dan corned, telah menjadi salah satu pilihan masyarakat sebagai produk pangan yang praktis. Nugget sudah banyak ditemukan di kalangan masyarakat saat ini, terutama yang terbuat dari ayam (Dewi dkk, 2015). Bahkan dari beberapa penelitian yang ada nugget dibuat dengan bahan dasar utama cumi-cumi yang ditambahkan dengan bahan makanan lain, misalnya dengan penambahan tepung labu kuning. 


\begin{abstract}
Cumi-cumi merupakan biota bernilai ekonomi tinggi. Keunggulannya adalah hampir semua bagian tubuhnya dapat dimakan, yakni mencapai $80 \%$. Sementara sebagai perbandingan, pada beberapa jenis ikan, bagian yang dimakan hanya $40-70 \%$. Selain itu, cumi-cumi mengandung zat-zat gizi yang sangat lengkap serta mengandung asam lemak tidak jenuh, khususnya jenis-jenis omega-3 yang sangat bermanfaat untuk kesehatan. Jenis produk olahan cumi sebagai konsumsi lokal masih sangat terbatas, diantaranya cumi asin, cumi kering, kerupuk cumi, dan pengalengan cumi (Nurhayati dkk. 2016).
\end{abstract}

Pemilihan bahan utama untuk membuat nugget dari cumi-cumi yaitu sebagai bentuk penganeka ragaman pada produk nugget serta melihat tingkat kesukaan konsumen dan mutu dari nugget cumi-cumi. Produk nugget yang banyak beredar dipasaran dan dikonsumsi oleh masyarakat yaitu nugget ayam. Namun sering dengan perkembangan zaman nugget telah dibuat dengan menggunakan bahan ikan. Karena itu peneliti ingin mencoba untuk membuat suatu olahan nugget dengan bahan utama cumi-cumi.

Makanan cepat saji biasanya mempunyai kelemahan pada kandungan seratnya, untuk itu diperlukan penambahan sayuran untuk meningkatkan kandungan serat (Idraswari dkk. 2017). Adapun sayuran yang akan ditambahkan dalam pembuatan nugget cumi-cumi adalah bayam, dimana seperti kita ketahui bayam mengandung zat gizi yang tinggi dan bayam juga mudah didapatkan sehingga bisa menjadi alternatif sumber zat gizi (Indraswari, 2017).

Bayam merupakan jenis sayuran yang memiliki manfaat yang baik untuk kesehatan, karena bayam mengandung banyak gizi dan vitamin yang bermanfaat untuk tubuh. Kandungan vitamin pada bayam sangatlah banyak diantaranya kandungan vitamin pada bayam yaitu vitamin $\mathrm{A}, \mathrm{B} 2, \mathrm{~B} 6, \mathrm{~B} 12, \mathrm{C}, \mathrm{K}$, mangan, magnesium, zat besi, kalsium, kalium, dan fosfor (Lingga, 2010).

Berdasarkan uraian diatas, maka penulis bermaksud membuat suatu modifikasi pangan yaitu daya terima serta analisis kadar protein dan fosfor pada nugget cumi-cumi dengan penambahan bayam sebagai makanan cepat saji yang bernilai gizi tinggi.

\section{BAHAN DAN METODE Jenis Penelitian}

Penelitian merupakan penelitian Laboratorium dengan desain penelitian yang digunakan adalah One Shoot Group Design.

\section{Tempat dan Waktu Penelitian}

Lokasi penelitian yaitu pada pembuatan nugget cumi-cumi dengan penambahan bayam dilakukan di Laboratorium IImu Teknologi Pangan Jurusan Gizi Politeknik Kesehatan Makassar, daya terima nugget cumi-cumi dengan penambahan bayam untuk panelis mahasiswa dilakukan di Laboratorium Organoleptik Jurusan Gizi Politeknik Kesehatan Makassar dan pada analisis kandungan zat gizi nugget cumi-cumi dengan penambahan bayam di Laboratorium Kimia Makanan Ternak, Jurusan Nutrisi dan Makanan Ternak, Fakultas peternakan, Universitas Hasanuddin Makassar. Waktu penelitian dilaksanakan pada bulan September 2019 Februari 2020.

\section{Alat dan Bahan}

Alat yang digunakan yaitu : Baskom, timbangan, cetakan/loyang, mangkok adonan, kukusan, nampan/pirang, wajan, sutil, irus, pisau dan talenan.

Bahan yang digunakan yaitu : cumicumi, bayam, tepung terigu, tepung tapioca, tepung panir, telur, merica bubuk, bawang putih, garam, jeruk nipis, air dan minyak goreng.

\section{Tahap Penelitian}

Pembuatan nugget cumi-cumi dengan penambahan bayam : siapkan semua bahan dan timbang. Mula-mula cumi-cumi dibersihkan dari kotoran. Kemudian cumicumi direndam dalam larutan jeruk nipis selama 2 menit, setelah itu bilas dengan air bersih. Bayam ditimbang sebanyak 12,5 gram (5\%), 25 gram (10\%) dan 37,5 gram $(15 \%)$, kemudian di blanching dan diiris tipis-tipis. Cumi-cumi di blender dengan 113 gram telur ayam, 1 gram merica bubuk, 9 gram bawang putih, 1 gram garam dan 50 $\mathrm{ml}$ air. Blender sampai semua bahan halus dan tercampur rata. Masukan tepung tapioca dan tepung terigu 25 gram di tambahkan kedalam adonan nugget, aduk kembali sampai rata. Adonan nugget cumicumi yang telah tercampur rata di tuang 
kedalam cetakan yang telah dilapisi dengan plastik wrap, setelah itu adonan nugget cumi-cumi di kukus diatas api sedang selama 20-30 menit. Biarkan dingin kemudian potong dengan bentuk kotak. Nugget cumi-cumi di celupkan ke bahan pencelup (telur ayam) dan di gulingkan diatas tepung panir. Lakukan sampain adonan habis, kemudian Nugget cumi-cumi digoreng diatas minyak panas sampai warna kuning keemasan dan nugget cumicumi dengan penambahan bayam siap dihidangkan.

\section{Jenis dan Cara Pengumpulan Data}

Jenis data yang diperoleh dalam penelitian ini adalah data primer yaitu daya terima dan analisis kandungan zat gizi protein dan fosfor. Daya terima diperoleh dari formulir yang diisi oleh panelis yang berisi 4 aspek yaitu warna, aroma, tekstur dan rasa sedangkan untuk analisis kandungan zar gizi diperoleh dari hasil uji laboratorium dengan menggunakan produk dari hasil daya terima yang paling disukai.

Cara pengumpulan data meliputi yang pertama tahap-tahap penilaian organoleptik yaitu : sebelum penilaian dilakukan produk yang akan dinilai diletakkan dalam wadah, formulir penilaian dan produk yang akan dinilai diletakkan diatas meja, panelis berjumlah 25 orang, selanjutnya diberi penjelasan singkat sehubungan dengan atribut yang dinilai, panelis diberi waktu \pm 15 menit untuk menilai produk, yang kedua penentuan kriteria panelis meliputi: panelis agak terlatih yaitu mahasiswa jurusan gizi Politeknik Kesehatan Makassar yang telah mendapatkan mata kuliah IImu Teknologi Pangan yang berjumlah 25 orang, panelis memahami tentang atribut yang akan dinilai, panelis dalam kondisi sehat dan panelis yang sudah sarapan, ketiga kriteria penilaian yaitu; masing-masing atribut dinilai menurut tingkat kesukaan panelis dengan menggunakan skala hedonik (Skor 4 jika sangat suka, skor 3 jika suka, skor 2 tidak suka dan skor 1 sangat tidak suka) dan yang keempat yaitu tahap penentuan kandungan zat gizi protein dan fosfor diperoleh dari hasil Micro Kjeldahl untuk kandungan protein dan hasil uji spektrofotometri AOAC 986.24 tahun 2012 untuk kandungan fosfor.

\author{
Pengolahan, Analisis dan Penyajian \\ Data \\ Data daya terima yang diperoleh
} kemudian diolah secara manual dengan menggunakan program Microsoft Excel dan Statistical Product and Service Solution (SPSS) sedangkan data analisis kandungan zat gizi protein dan fosfor diolah menggunakan program Microsoft Word. Data yang diperoleh dianalisis dengan menggunakan uji statistik yaitu uji Friedman Test yang digunakan dengan uji lanjut Wilcoxon untuk melihat adanya perbedaan tingkat kesukaan terhadap nugget cumicumi dengan penambahan bayam konsentrasi $0 \%, 5 \%, 10 \%$, dan $15 \%$. Data yang telah diolah dan dianalisis selanjutnya disajikan dalam bentuk tabel dan narasi.

\section{HASIL PENELITIAN}

\section{a. Aspek Warna}

Tabel 1 menunjukkan bahwa penilaian panelis dari aspek warna yang paling tidak disukai panelis yaitu nugget cumi-cumi konsentrasi $15 \%$ sebanyak 11 panelis (44.0\%).

Hasil analisis menggunakan Friedman test menunjukkan nilai $p<0,000$ lebih kecil dari nilai alpa $(0,05)$ artinya, terdapat perbedaan kesukaan warna nugget cumi-cumi dengan penambahan bayam disetiap formula. Formula yang menunjukkan perbedaan berdasarkan uji lanjut Wilcoxon yaitu X1 dan X2 $(p=0,029)$, $\mathrm{X} 1$ dan $\mathrm{X} 3(p=0,007), \mathrm{X} 1$ dan $\mathrm{X} 4 \quad(p=$ $0,001), X 2$ dan $X 4(p=0,003)$ dan $X 3$ dan $\mathrm{X} 4(p=0,020)$.

\section{b. Aspek Aroma}

Tabel 2 menunjukkan bahwa penilaian panelis dari aspek aroma yang paling tidak disukai yaitu nugget cumi-cumi konsentrasi $15 \%$ sebanyak 6 panelis $(24,0 \%)$.

Hasil analisis menggunakan Friedman test menunjukkan nilai $p<0,000$ lebih kecil dari nilai alpa $(0,05)$ artinya, terdapat perbedaan dari aspek aroma nugget cumi-cumi dengan penambahan bayam disetiap formula. Formula yang menunjukkan perbedaan berdasarkan uji lanjut Wilcoxon yaitu X1 dan X2 $(p=0,004)$, $\mathrm{X} 1$ dan $\mathrm{X} 3(p=0,012)$ dan X1 dan X4 $(p=$ $0,000)$. 


\section{c. Aspek Tekstur}

Tabel 3 menunjukkan bahwa penilaian panelis dari aspek tekstur yang paling tidak disukai yaitu kue bangke konsentrasi $15 \%$ sebanyak 4 panelis (16.0\%).

Hasil analisis menggunakan Friedman menunjukkan nilai $p>0,543$ lebih besar dari nilai alpa $(0,05)$ artinya, tidak terdapat perbedaan kesukaan tekstur nugget cumi-cumi dengan penambahan bayam disetiap formula.

\section{d. Aspek Rasa}

Tabel 4 menunjukkan bahwa penilaian panelis dari aspek rasa yang paling tidak disukai yaitu kue bangke konsentrasi $15 \%$ sebanyak 8 panelis (32.0\%).

Hasil analisis menggunakan Friedman test menunjukkan nilai $p<0,025$ lebih kecil dari nilai alpa $(0,05)$ artinya, terdapat perbedaan dari aspek rasa nugget cumi-cumi dengan penambahan bayam disetiap formula. Formula yang menunjukkan perbedaan berdasarkan uji lanjut Wilcoxon yaitu X1 dan X4 $(p=0,007)$.

\section{e. Analisis Zat Gizi Protein}

Hasil uji laboratorium pada tabel 5 menunjukkan kandungan protein per 100 gram pada nugget cumi-cumi dengan penambahan bayam dengan pengulangan sebanyak 2 kali (duplo) dengan konsentrasi $0 \%$ yang masing-masing $13,17 \mathrm{~g}$ dan 13,73 $\mathrm{g}$ dengan nilai rata-rata dari dua kali pengulangan adalah $13,45 \mathrm{~g}$. Sedangkan konsentrasi $5 \%$ yaitu masing-masing 15,81 $\mathrm{g}$ dan $15,17 \mathrm{~g}$ dengan nilai rata-rata 15,49 g. Maka ada peningkatan jumlah kandungan protein dalam nugget cumicumi.

\section{f. Analisis Zat Gizi Fosfor}

Hasil uji laboratorium pada tabel 6 menunjukkan kandungan Fosfor per 100 gram pada nugget cumi-cumi dengan penambahan bayam dengan pengulangan sebanyak 2 kali (duplo) dengan konsentrasi $0 \%$ yang masing-masing $75 \mathrm{mg}$ dan $72 \mathrm{mg}$ dengan nilai rata-rata dari dua kali pengulanan adalah 73,5 mg. Sedangkan konsentrasi $5 \%$ yaitu masing-masing $94 \mathrm{mg}$ dan $95 \mathrm{mg}$ dengan nilai rata-rata $94,5 \mathrm{mg}$. Maka ada peningkatan jumlah kandungan protein dalam nugget cumi-cumi.

\section{PEMBAHASAN \\ Daya Terima Terhadap Nugget Cumi- Cumi Dengan Penambahan Bayam.}

\section{Aspek warna}

Warna merupakan salah satu faktor yang sangat penting dalam peneriaan atau penolakan suatu produk karena kesan pertama yang dilihat panelis. Warna merupakan hal yang pertama kali mempengaruhi seseorang untuk menentukan suka atau tidak suka terhadap produk tersebut (Fitri, dkk, 2017).

Hasil penilaian panelis terhadap nugget cumi-cumi dengan penambahan bayam menunjukkan bahwa dari aspek warna yang paling tidak disukai yaitu nugget cumi-cumi X4 (konsentrasi 15\%) sebanyak 11 panelis (44,0\%). Artinya semakin tinggi penambahan konsentrasi bayam maka semakin rendah daya terimanya.

Hasil analisis menggunakan friedman test menunjukkan nilai $p>0,000$ lebih kecil dari nilai alpa $(0,05)$ artinya, terdapat perbedaan kesukaan warna nugget cumi-cumi dengan penambahan bayam disetiap formula. Formula yang menunjukkan perbedaan berdasarkan uji lanjut Wilcoxon yaitu X1 dan X2 $(p=0,029)$, $\mathrm{X} 1$ dan X3 $(p=0,007), \mathrm{X} 1$ dan X4 ( $p=$ $0,001), X 2$ dan $X 4(p=0,003)$ dan $X 3$ dan $\mathrm{X} 4(p=0,020)$.

Penelitian ini sejalan dengan peneltian yang dilakukan (Indraswari, 2017) berdasarkan uji Hedonik menunjukkan bahwa nugget kaki naga lele tanpa penambahan bayam mendapatkan skor tertinggi, sedangkan nilai terendah yaitu pada penambahan bayam $40 \%$. Semakin banyak penambahan bayam semakin tidak disukai panelis dari segi warna, hal ini dikarenakan bayam memiliki zat warna alami hijau (klorofil), apabila bayam dicampurkan terlalu banyak, maka warna hijau pada bayam akan berpengaruh pada kepekatan warna yang memberikan efek warna lebih gelap pada makanan.

\section{Aspek Aroma}

Aroma makanan berasal dari molekul-molekul yang menguap dari makanan yang kemudian ditangkap oleh hidung sebagai indera pembau. Aroma makanan merupakan salah satu aspek dari rasa makanan. Aroma yang disebarkan oleh makanan menghasilkan daya tarik 
yang sangat kuat dan mampu merangsang indera (Rijadi, 2012).

Aspek aroma yang paling tidak disukai yaitu nugget cumi-cumi X4 (konsentrasi 15\%) sebanyak 6 panelis (24.0\%). Artinya semakin tinggi penambahan konsentrasi bayam maka semakin rendah daya terimanya.

$$
\text { Berdasarkan hasil analisis }
$$

menggunakan uji friedman test menunjukkan nilai $p>0,000$ lebih kecil dari nilai alpa $(0,05)$ artinya, terdapat perbedaan kesukaan aroma nugget cumi-cumi dengan penambahan bayam disetiap formula. Formula yang menunjukkan perbedaan berdasarkan uji wilcoxon yaitu $\mathrm{X} 1$ dan $\mathrm{X} 2$ $(p=0,004), \mathrm{X} 1$ dan $\mathrm{X} 3(p=0,012)$ dan $\mathrm{X} 1$ dan X4 $(p=0,000)$.

Penelitian ini sejalan dengan (Aprilianingtyas, 2009) yaitu nilai yang diberikan panelis terhadap parameter aroma empek-empek dengan konsentrasi bayam berkisar antara 2,77 (tidak suka) hingga 4,03 (agak suka). Nilai hedonik parameter aroma cenderung menurun dengan semakin bertambahnya konsentrasi bayam yang digunakan.

\section{Aspek Tekstur}

Tekstur merupakan atribut penilaian yang mempengaruhi penerimaan panelis terhadap daya terima. Tekstur bersifat kompleks dan dengan struktur bahan yang terdiri dari tiga elemen yaitu: mekanik (kekerasan, kekanyalan), geometrik (berpasir, beremah), dan mouthfeel (berminyak, berair) (Setyaningsih, dkk,2010).

Aspek tekstur yang paling tidak disukai yaitu nugget cumi-cumi X4 (konsentrasi 15\%) sebanyak 4 panelis (16.0\%). Artinya semakin tinggi penambahan konsentrasi bayam maka semakin rendah daya terimanya.

Hasil analisis menggunakan uji Friedman test menunjukan nilai $p>0,543$ yang berarti bahwa tidak terdapat perbedaan kesukaan tekstur nugget cumicumi dengan penambahan bayam disetiap formula.

Berdasarkan hasil penelitian (Indraswari, 2017) hasil uji hedonik menunjukkan bahwa nugget dengan penambahan bayam sebesar $30 \%$ memiliki nilai tertinggi, dan nilai terendah yaitu nugget dengan penambahan bayam sebesar $40 \%$. Tekstur pada pada nugget dipengaruhi oleh bahan pembuatan dan proporsi bahan yang ditambahkan.

\section{Aspek Rasa}

Rasa merupakan aspek penting dalam menilai suatu makanan tertentu dengan menggunakan panca indera pengecap dan erupakan hal kedua setelah penampilan makanan dalam membentuk pilihan terhadap makanan dan orang-orang menilai cita rasa sebagai alasan utama untuk memilih makanan tertentu, setiap orang memiliki kepekaan berbeda-beda dalam menilai suatu produk/makanan (Fellows, 2014).

Aspek rasa yang paling tidak disukai yaitu nugget cumi-cumi X4 (konsentrasi $15 \%$ ) sebanyak 8 panelis (32.0\%). Artinya semakin tinggi penambahan konsentrasi bayam maka semakin rendah daya terimanya.

Berdasarkan hasil analisis $\mathrm{Uji}$ Friedman test menunjukkan nilai $p>0,025$ lebih kecil dari nilai alpa $(0,05)$ artinya, terdapat perbedaan kesukaan rasa nugget cumi-cumi dengan penambahan bayam disetiap formula. Formula yang menunjukkan perbedaan berdasarkan uji lanjutu Wilcoxon yaitu X1 dan X4 ( $p=$ 0,007).

Penelitian ini sejalan dengan penelitian yang dilakukan (Simanjuntak L, 2016) berdasarkan hasil uji daya terima terhadap rasa oleh panelis menunjukkan bahwa panelis menyukai rasa biskuit mocaf dengan penambahan tepung bayam $10 \%$. Biskuit mocaf dengan penambahan tepung bayam 20\% juga berada dalam kriteria suka, biskuit mocaf dengan penambahan tepung bayam 10\% memiliki skor lebih tinggi yaitu $74(82,2 \%)$, sedangkan hasil penelitian biskut mocaf dengan penambahan tepung bayam $20 \%$ memiliki skor $71(78,9 \%)$.

\section{Analisis Kandungan Zat Gizi Protein pada Nugget Cumi-Cumi dengan Penambahan Bayam.}

Protein merupakan suatu zat yang sangat penting bagi tubuh, karenazat ini mempunyai fungsi utama yaitu sebagai zat pembangun dalam tubuh dan juga berfungsi sbagai zat pengatur (Sari, 2011). Hasil analisis kandungan protein pada nugget cumi-cumi dengan penambahan bayam (konsentrasi 0\%) mengandung protein sebanyak $13,45 \mathrm{gr}$ per $100 \mathrm{gr}$ berat bahan sedangakan, pada penambahan 
bayam (konsentrasi 5\%) sebanyak $15,49 \mathrm{gr}$ per $100 \mathrm{gr}$ berat bahan. Hal ini menunjukkan bahwa dengan adanya penambahan bayam maka kandungan protein dari nugget cumi-cumi dapat sedikit meningkat dibandingkan tanpa penambahan bayam.

Hal ini sejalan dengan penelitian yang dilakukan oleh (Daulay, 2015) Uji Daya Terima dan Nilai Gizi Donat yang Dimodifikasi dengan Tepung Biji Nangka dan Tepung Bayam yang menyatakan bahwa semakin banyak tepung bayam yang dicampurkan dalam adonan donat maka semakin banyak pula kandungan proteinnya. Dimana kandungan protein donat $A 1$ memberi sumbangan $9,77 \%$ dan Donat A2 memberi sumbangan $10,1 \%$.

Berdasarkan AKG 2019 kebutuhan harian protein untuk anak-anak meningkat sesuai usia yaitu anak usia 1-3 tahun adalah $20 \mathrm{gr} / \mathrm{hari}$ dan anak usia 4-6 tahun adalah $25 \mathrm{gr} /$ hari maka $20 \%$ dari $20 \mathrm{gram}$ adalah 4 gram dan $20 \%$ dari 25 gram adalah 5 gram. Nugget cumi-cumi dengan penambahan bayam konsentrasi $0 \%$ dengan kandungan protein 2,69 gr per potong, untuk memenuhi kriteria tinggi protein jumlah nugget yang harus dikonsumsi anak 1-3 tahun yaitu 2-3 potong nugget perhari. Konsentrasi $5 \%$ dengan kandungan protein $3,1 \mathrm{gr}$ per potong maka nugget yang harus dikonsumsi yaitu 2-3 potong nugget perhari untuk anak balita 1-3 tahun. Untuk anak usia 4-6 tahun jumlah nugget yang harus dikonsumsi per hari yaitu 3-4 potong nugget cumi-cumi perhari pada setiap konsentrasi.

\section{Analisis Kandungan Zat Gizi Fosfor pada Nugget Cumi-Cumi dengan Penambahan Bayam. \\ Fosfor merupakan salah satu} mineral terbanyak dalam tubuh yang jumlahnya hanya di lampaui oleh kalsium. Fosfor termasuk golongan mineral makro yang dibutuhkan tubuh dalam jumlah lebih dari $100 \mathrm{mg}$ sehari ( $>0,05 \%$ berat badan) (Ritonga, 2012). Hasil analisis kandungan fosfor pada nugget cumi-cumi dengan penambahan bayam (konsentrasi $0 \%$ ) mengandung protein sebanyak $73,5 \mathrm{mg}$ per $100 \mathrm{gr}$ berat bahan sedangakan, pada penambahan bayam (konsentrasi $5 \%$ ) sebanyak $94,5 \mathrm{mg}$ per $100 \mathrm{gr}$ berat bahan. Hal ini menunjukkan bahwa dengan adanya penambahan bayam maka kandungan fosfor dari nugget cumi-cumi dapat meningkat dibandingkan tanpa penambahan bayam.

Berdasarkan AKG 2019 kebutuhan harian fosfor untuk anak-anak meningkat sesuai usia yaitu anak usia 1-3 tahun adalah $460 \mathrm{mg} / \mathrm{hari}$ dan anak usia 4-6 tahun adalah $500 \mathrm{mg} /$ hari maka $15 \%$ dari $460 \mathrm{mg}$ adalah $69 \mathrm{mg}$ dan $15 \%$ dari $500 \mathrm{mg}$ adalah $75 \mathrm{mg}$ kandungan fosfor yang harus dipenuhi. Nugget cumi-cumi dengan penambahan bayam kosentrasi $0 \%$ dengan kandungan fosfor $14,7 \mathrm{mg}$ per potong, konsentrasi $5 \%$ dengan kandungan fosfor $94,5 \mathrm{mg}$ per potong. Untuk memenuhi kebutuhan fosfor jumlah nugget cumi-cumi yang dikonsumsi adalah 3-5 potong nugget.

\section{KESIMPULAN DAN SARAN}

Hasil penilaian

panelis

menunjukkan bahwa nugget cumi-cumi dengan penambahan bayam yang paling banyak disukai yaitu pada konsentrasi $0 \%$ sebanyak 335 skor dan 5\% sebanyak 309 skor. Hasil analisis kandungan protein tertinggi per 100 gram berat bahan pada nugget cumi-cumi dengan penambahan bayam terdapat pada nugget dengan konsentrasi $5 \%$ yaitu $15,49 \%$ dan hasil analisi kandungan fosfor tertinggi per 100 gram berat bahan pada nugget cumi-cumi dengan penambahan bayam terdapat pada nugget dengan konsentrasi $5 \%$ yaitu $0,094 \%$. Hasil uji statistik friedman test menunjukkan bahwa nugget cumi-cumi dengan penambahan bayam berdasarkan sifat organoleptik menunjukkan terdapat perbedaan dari aspek warna $(p=0,000)$, aspek aroma $(p=0,000)$ dan aspek rasa $(p=$ 0,025 ) nugget cumi-cumi pada setiap konsentrasi. Sedangkan untuk aspek tekstur $(p=0,543)$ berdasarkan uji friedman tes menunjukkan tidak terdapat pada nugget cumi-cumi pada setiap konsentrasi.

Penelitian ini menjadi dasar bagi peneliti selanjutnya untuk meneliti kandungan zat gizi lain yang terkandung pada cumi-cumi dengan penambahan bayam dan dapat menambahkan bahan lain pada produk nugget cumi-cumi ini untuk lebih meningkatkan daya terima dan nilai gizinya.

\section{DAFTAR PUSTAKA}

Achmad Djaeni Sediaoetama. 2004. IImu Gizi untuk Mahasiswa dan Profesi. Edisi Kelima. Jakarta : Dian Rakyat 
Agusandi, Supriadi, A \& Lestari S.D. 2013. Pengaruh Penambahan Tinta CumiCumi (Loligo sp) terhadap Kualitas Nutrisi dan Penerimaan Sensoris Mi Basah. Fishtech. Volume II (1), 2013

Almatsier, S. 2013. Prinsip Dasar Ilmu Gizi. Gramedia Pustaka Utama.Jakarta

Andriyani, M \& Bambang, W. 2014. Pengantar Gizi Masyarakat. Jakarta: Kencana Prenada Media Group.

Angka Kecukupan Gizi (AKG). (2019). Angka Kecukupan Gizi Yang Dianjurkan Bagi Bangsa Indonesia.Jakarta.

Anonim 2010. Statistik perikanan Indonesia. Direktorat Jenderal Perikanan, Departemen Pertanian, Jakarta.

Anonim 2014. Bayam. http://id.wikipedia. org/wiki/Bayam. 19 Januari 2020.

Antong \& Maharani A. 2017. Pengolahan Sayur Bayam menjadi Es Krim di Kelurahan Purangi Kecamatan Sendana Kota Palopo. Jurnal Equilibrium. Volume VI (1), 2017

Aprilianingtyas, Y. 2009. Pengembangan Produk Empek-Empek Palembang dengan Penambahan Sayuran Bayam dan Wortel Sebagai Sumber Serat Pangan. Skripsi. Bogor. Fakultas Teknologi Pertanian, Institut Pertanian Bogor.

Badan Standarisasi Nasional (BSN). 2002. Nugget Ayam SNI 01-6683-2002. Jakarta: Badan Standarisasi Nasional Indonesia.

Badan Pengawas Obat dan Makanan (BPOM), 2004. Pedoman Umum Pelabelan Produk Pangan. Jakarta. Direktorat Standarisasi Produk Pangan.

Daulay, SR, dkk. 2015. Uji Daya Terima dan Nilai Gizi Donat yang Dimodifikasi dengan Tepung Biji Nangka dan Tepung Bayam. FKM USU. Medan.

Dewi T, dkk. 2015. Daya Terima terhadap Nugget Ikan Layang (Decapterus Russelli) dengan Penambahan Wortel. Media Gizi Pangan. Volume XIX (1), 2015

Dinas Kelautan dan Perikanan. 2010 dalam Susiana dan Rochmady. 2018. Pendugaan Stock Cui-cumi Loligo sp. di Perairan Kabupaten Pangkajene dan Kepulauan, Sulawesi Selatan, Indonesia.Jurnal
Pengolahan Perairan. Volume 1 (1), 2018

Dwijayanthi L. 2012. IImu Gizi Menjadi Sangat Mudah. Jakarta; Buku Kedokteran EGC.

Fellows, P.J. (2014). Teknologi Pengelolahan Pangan Prinsip dan Praktik. Jakarta: Penerbit Buku Kedokteran EGC.

Firdaus, A. 2014. Perbandingan Kadar Nitrit (NO2-) pada Sayur Bening Sewaktu dengan Didiamkan pada Suhu Ruang. Analis Kesehatan Poltekkes Banjarmasin

Fitri N \& Purwani E. (2017). Pengaruh Subsitusi Tepung Ikan Kembung (Rastrelliger Brachysoma) Terhadap Kadar Protein dan Daya Terima Biskuit. Seminar Nasional Gizi. ISSN: 2579-9622

Fredlina, J. \& Malik, R. 2018. Hubungan Status Gizi terhadap Anemia pada Balita di Kelurahan Tomang Kecamatan Grogol Petamburan Jakarta Barat Periode Januari 2015. Tarumanegara Medical Journal. Volume 1(1), 2018

Ginting, Nurzainah, Namida Umar. 2005. Penggunaan Berbagai Bahan Pengisi pada Nugget Itik Air. Jurnal Agrobisnis Peternakan. Volume 1 (3), 2005.

Indraswari, D. H, Ningtyias, F.W \& Rohmawati, N. 2017. Pengaruh Penambahan Bayam (Amaranthus tricolor) pada 'Nugget' Kaki Naga Lele (Clarias gariepinus) terhadap Kadar Zat Bezi, Protein dan Air. Penelitian Gizi dan Makanan. Volume 40(1), Juni 2017

Kompas. 2011 dalam Anggeraini, A. 2012. Pengaruh Jumlah Wortel dan Lama Pengukusan terhadap Mutu Nugget. Skripsi. Fakultas Pertanian. Universitas Sumatera Utara.

Lingga, L. 2010. Cerdas Memilih Sayuran. Jakarta: Agromedia Pustaka.

Mahayani, A, dkk. 2014. Pengaruh Penambahan Bayam terhadap Kualitas Mie Basah. Jurnal Agroknow. Volue 2 (1), 2014

Nugroho A, Swastawani F, dan Anggo D. 2014. Pengaruh bahan pengikat waktu penggorengan terhadap mutu produk nugget kaki naga tengiri. Jurnal Pengolahan dan Bioteknologi Hasil Pertanian. 2014;4:140-143. 
Nurhayati, L. Suparmi \& Sari, NI. 2016. Kajian Formulasi Nugget Cumi-Cumi (Loligo sp) dengan Penambahan Tepung Labu Kuning (Curcubita moschata).

Okuzumi \& Fuji. 2000 dalam Arby, A, Desmelati \& Sumarto. 2015. Pengaruh Penggunaan Tepung Ubi Jalar Ungu (Ipomoea batatas) terhadap Mutu Nugget Cumi-Cumi (Loligo sp.)

Omar. 2002 dalam Aras, M. \& Hasmawati. 2016. Karakteristik substrat untuk penempelan telur cumi-cumi di Pulau Pute Anging Kabupaten Barru. Jurnal Galung Tropika. Volume 5 (1), 2016

Rijadi, C. 2012. Hubungan rasa makanan, penampilan makanan dan faktor lainnya terhadap daya terima makanan lunak pada pasien RSPAD Gatot Subroto. Skripsi. Depok: Fakultas Kesehatan Masyarakat Universitas Indonesia.

Ritonga, PS \& Sukindro. 2012. Analisis Kandungan Fosfor Menggunakan Spectrofotometer UV-Vis pada Kacang Hijau yang Diambil Dari Pasar Kota PekanBaru. Jurnal Photon. Volume 2 (2), 2012

Rochmady, R. \& Susiana, S. 2014. Pendugaan Stok Ikan Kerapu (Grouper) di Perairan Selat Makassar Sulawesi Selatan Periode Tahun 1999-2007. Agrikan: Jurnal Agribisnis dan Perikanan. Volume 7(2), 2014

Saparinto, C. 2013. Grow your own vegetables-panduan praktis menanam 14 Sayuran Konsumsi Populer di Pekarangan. Yogyakarta: Penebar Swadaya. $180 \mathrm{hlm}$.

Sediaoetama AD. 2012. IImu Gizi untuk Mahasiswa dan Profesi. Jakarta; Dian Rakyat.

Setyaningsih D, dkk. (2010). Analisi sensori untuk industri pangan dan Agro. Bogor : Institut Pertanian Bogor
Simanjuntak, L. 2016. Uji daya terima dan nilai gizi biskuit mocaf dengan penambahan tepung bayam. Skripsi. Medan: Fakultas Kesehatan Masyarakat Universitas Sumatera Utara.

Suwoyo, H. 2006. Pengembangan Produk Chicken Nugget vegetable Berbahan Dasar Daging SBB (Skinles Boneless breast) dengan Penambahan Flakes Wortel di Pt. Charoen Pokphand Indonesia Chicken Processing Plant, Cikande-Serang. Skripsi thesis: Institut Pertanian bogor.

Syamri. 2011. Nugget Ayam Bukan Makanan Sampah. www.ilmupangan. blogspot.com. Diakses : 1 April 2019

Tabel Komposisi Pangan Indonesia (TKPI). 2017. Kementerian Kesehatan Republik Indonesia.

Tamtomo, Danny S .2016. Sedap Paduan Cita Rasa Dan Kuliner. Jakarta: PT Gramedia

Virdias, \& Rahmania, T. 2013. Life Good with Green: Kandungan Nutrisi Bayam, http://umow.blogspot.com

Waryana. 2010. Gizi Reproduksi. Yogyakarta: Pustaka Rahima

Wijayanto, A. 2015. Budidaya 10 Sayuran Paling Favorit. Yogyakarta: Ariska

Yunirahnnisa SG. (2018). Analisis Nilai Gizi Makro Pada Biskuit Tepung Kacang Gude (Cajanus Cajan) dan Tepung Mocaf (Modifikasi Cassava). Karya Tulis. Jurusan Gizi Politeknik Kesehatan Makassar.

Zakaria,dkk (2009). Bahan Ajar IImu Teknologi Pangan. Politeknik Kesehatan Depkes Makassar.

Zulhendri, M. Buchari, D \& Suparni. 2015. Studi Penerimaan Konsumen Terhadap Nugget Cumi-Cumi (Ioligi sp) kering Asin. JOM. 2015. 
Tabel 1

Distribusi Daya Terima Terhadap Aspek Warna

Nugget Cumi-Cumi dengan Penambahan Bayam

\begin{tabular}{ccccccccccccc}
\hline & \multicolumn{1}{c}{ Daya Terima } & \multicolumn{2}{c}{ Sangat } & Total & Nilai $p$ \\
Formula & $\begin{array}{c}\text { Sangat } \\
\text { Suka }\end{array}$ & \multicolumn{2}{c}{ Suka } & $\begin{array}{c}\text { Tidak } \\
\text { Suka }\end{array}$ & $\begin{array}{c}\text { Sidak } \\
\text { Suka }\end{array}$ & & & \\
\cline { 2 - 13 } & $\mathrm{N}$ & $\%$ & $\mathrm{~N}$ & $\%$ & $\mathrm{~N}$ & $\%$ & $\mathrm{~N}$ & $\%$ & $\mathrm{~N}$ & $\%$ & \\
\hline X1 & 12 & 48.0 & 13 & 52.0 & 0 & 0 & 0 & 0 & 25 & 100.0 & \\
X2 & 4 & 16.0 & 20 & 80.0 & 1 & 4.0 & 0 & 0 & 25 & 100.0 & 0.000 \\
X3 & 3 & 12.0 & 16 & 64.0 & 6 & 24.0 & 0 & 0 & 25 & 100.0 & \\
X4 & 1 & 4.0 & 13 & 52.0 & 11 & 44.0 & 0 & 0 & 25 & 100.0 & \\
\hline
\end{tabular}

Sumber: Data Primer, terolah, 2020

X1: Nugget cumi-cumi tanpa penambahan bayam ( $0 \%)$

$X 2$ : Nugget cumi-cumi dengan penambahan bayam (5\%)

X3: Nugget cumi-cumi dengan penambahan bayam $(10 \%)$

X4: Nugget cumi-cumi dengan penambahan bayam (15\%)

\section{Tabel 2}

Distribusi Daya Terima Terhadap Aspek Aroma

Nugget Cumi-Cumi dengan Penambahan Bayam

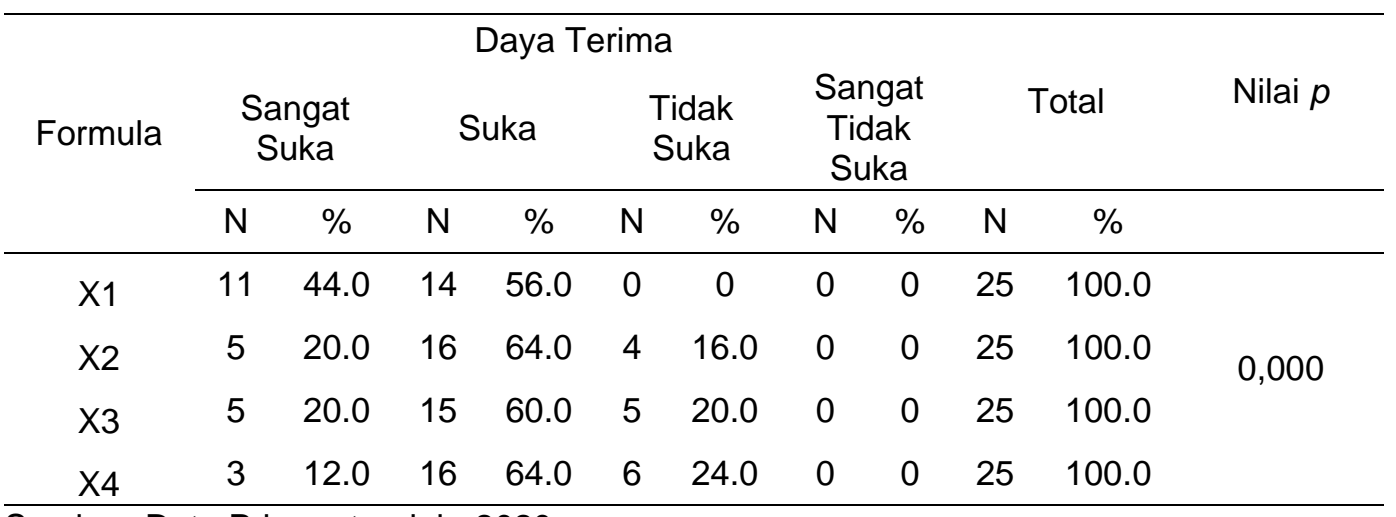

Sumber: Data Primer, terolah, 2020

X1: Nugget cumi-cumi tanpa penambahan bayam (0\%)

X2: Nugget cumi-cumi dengan penambahan bayam (5\%)

X3: Nugget cumi-cumi dengan penambahan bayam (10\%)

X4: Nugget cumi-cumi dengan penambahan bayam (15\%) 


\section{Tabel 3}

Distribusi Daya Terima Terhadap Aspek Tekstur Nugget Cumi-Cumi dengan Penambahan Bayam

\begin{tabular}{|c|c|c|c|c|c|c|c|c|c|c|c|}
\hline \multirow{3}{*}{ Formula } & \multicolumn{10}{|c|}{ Daya Terima } & \multirow{3}{*}{ Nilai $p$} \\
\hline & \multicolumn{2}{|c|}{$\begin{array}{c}\text { Sangat } \\
\text { Suka }\end{array}$} & \multicolumn{2}{|c|}{ Suka } & \multicolumn{2}{|c|}{$\begin{array}{l}\text { Tidak } \\
\text { Suka }\end{array}$} & \multicolumn{2}{|c|}{$\begin{array}{c}\text { Sangat } \\
\text { Tidak } \\
\text { Suka }\end{array}$} & \multicolumn{2}{|c|}{ Total } & \\
\hline & $\mathrm{N}$ & $\%$ & $N$ & $\%$ & $\mathrm{~N}$ & $\%$ & $\mathrm{~N}$ & $\%$ & $\mathrm{~N}$ & $\%$ & \\
\hline $\mathrm{X} 1$ & 7 & 28.0 & 15 & 60.0 & 3 & 12.0 & 0 & 0 & 25 & 100.0 & \\
\hline $\mathrm{x} 2$ & 4 & 16.0 & 19 & 76.0 & 2 & 8.0 & 0 & 0 & 25 & 100.0 & 0,543 \\
\hline X3 & 3 & 12.0 & 19 & 76.0 & 3 & 12.0 & 0 & 0 & 25 & 100.0 & \\
\hline$X 4$ & 2 & 8.0 & 19 & 76.0 & 4 & 16.0 & 0 & 0 & 25 & 100.0 & \\
\hline
\end{tabular}

Sumber: Data Primer, terolah, 2020

X1: Nugget cumi-cumi tanpa penambahan bayam (0\%)

$X 2$ : Nugget cumi-cumi dengan penambahan bayam (5\%)

X3: Nugget cumi-cumi dengan penambahan bayam $(10 \%)$

X4: Nugget cumi-cumi dengan penambahan bayam (15\%)

\section{Tabel 4}

Distribusi Daya Terima Terhadap Aspek Rasa

Nugget Cumi-Cumi dengan Penambahan Bayam

\begin{tabular}{|c|c|c|c|c|c|c|c|c|c|c|c|}
\hline \multirow{3}{*}{ Formula } & \multicolumn{8}{|c|}{ Daya Terima } & & & \multirow{3}{*}{ Nilai $p$} \\
\hline & \multicolumn{2}{|c|}{$\begin{array}{l}\text { Sangat } \\
\text { Suka }\end{array}$} & \multicolumn{2}{|c|}{ Suka } & \multicolumn{2}{|c|}{$\begin{array}{l}\text { Tidak } \\
\text { Suka }\end{array}$} & \multicolumn{2}{|c|}{$\begin{array}{l}\text { Sangat } \\
\text { Tidak } \\
\text { Suka }\end{array}$} & \multicolumn{2}{|c|}{ Total } & \\
\hline & $\mathrm{N}$ & $\%$ & $\mathrm{~N}$ & $\%$ & $\mathrm{~N}$ & $\%$ & $\mathrm{~N}$ & $\%$ & $\mathrm{~N}$ & $\%$ & \\
\hline $\mathrm{X} 1$ & 9 & 36.0 & 15 & 60.0 & 1 & 4.0 & 0 & 0 & 25 & 100.0 & \\
\hline X2 & 7 & 28.0 & 14 & 56.0 & 4 & 16.0 & 0 & 0 & 25 & 100.0 & 0.025 \\
\hline X3 & 6 & 24.0 & 16 & 64.0 & 3 & 12.0 & 0 & 0 & 25 & 100.0 & \\
\hline $\mathrm{X} 4$ & 4 & 16.0 & 13 & 52.0 & 8 & 32.0 & 0 & 0 & 25 & 100.0 & \\
\hline
\end{tabular}

Sumber: Data Primer, terolah, 2020

X1: Nugget cumi-cumi tanpa penambahan bayam (0\%)

X2: Nugget cumi-cumi dengan penambahan bayam (5\%)

X3: Nugget cumi-cumi dengan penambahan bayam (10\%)

$X 4$ : Nugget cumi-cumi dengan penambahan bayam (15\%) 


\section{Tabel 5}

Hasil Analisis Kandungan Protein Nugget Cumi-Cumi Dengan Penambahan Bayam

\begin{tabular}{ccccc}
\hline \hline No & Konsentrasi & Satuan & $\begin{array}{c}\text { Hasil } \\
\text { Laboratorium }\end{array}$ & Rata-Rata \\
\hline 1 & Nugget cumi-cumi 0\% a & $\mathrm{g}$ & 13,17 & 13,45 \\
2 & Nugget cumi-cumi 0\% b & $\mathrm{g}$ & 13,73 & \\
3 & Nugget cumi-cumi 5\% a & $\mathrm{g}$ & 15,81 & 15,49 \\
4 & Nugget cumi-cumi 5\% b & $\mathrm{g}$ & 15,17 & \\
\hline
\end{tabular}

Sumber : Data Primer, Uji Laboratorium 2020

Tabel 6

Hasil Analisis Kandungan Fosfor Nugget Cumi-Cumi Dengan Penambahan Bayam

\begin{tabular}{ccccc}
\hline \hline No & Konsentrasi & Satuan & $\begin{array}{c}\text { Hasil } \\
\text { Laboratorium }\end{array}$ & Rata-Rata \\
\hline 1 & Nugget cumi-cumi 0\% a & $\mathrm{mg}$ & 75 & 73,5 \\
2 & Nugget cumi-cumi 0\% b & $\mathrm{mg}$ & 72 & \\
3 & Nugget cumi-cumi 5\% a & $\mathrm{mg}$ & 94 & 94,5 \\
4 & Nugget cumi-cumi 5\% b & $\mathrm{mg}$ & 95 & \\
\hline
\end{tabular}

Sumber : Data Primer, Uji Laboratorium 2020 